\title{
NOTICE
}

\section{Publications: Available or Forthcoming}

\section{1) Index of Titles and Authors in Environmental Conservation*}

The Index for 1974-86 (both inclusive), and its first Supplement (covering the years 1987 and 1988 ), are still available from the undersigned at the price (including surface postage) of US $\$ 40^{\dagger}$ or $60^{\dagger}$ Swiss francs as long as stocks last. It is anticipated that most of our subscribers, at least, will wish to purchase a copy of this pioneering Index of which the first part, with its 9,399 entries occupying 159 pages in the format of the Journal, alone approaches twice the basic length of one of our issues but still costs less!

Moreover this price will include full payment also for a further Supplement, covering the 5 years 1989-93, which is due to be sent in 1994 free to all registered purchasers of the original Index.

Referencing, as it does, surely the vast majority of leading Authors and topics that emerged during the formative years of the environmental-conservational movement or 'revolution', the Index with its Supplements should represent a valuable tool for researchers and a propitious guide for writers. This was borne out by our own experience during its original compilation, when already it proved to be a most useful work of reference, '... altogether constituting a unique chronicle of the environmental-conservational concerns of modern times' (according to the Foreword by the then Executive Director of the United Nations Environment Programme, Dr Mostafa K. Tolba).

\section{2) Full Sets and Back Numbers of Environmental Conservation}

We still have a few complete sets of Environmental Conservation, from its beginning with the Spring issue of 1974, available for purchase by or for worthy 'homes'. Back numbers can usually be supplied to fill gaps at a cost of US \$10 apiece.

3) Copies of Ecosystem Theory and Application

We also have some residual copies available (at US \$40 each, including postage) of Ecosystem Theory and Application, published in 1986 by John Wiley \& Sons in the President's series of Environmental Monographs \& Symposia.

\section{4) Publication of Environmental Challenges}

In July 1993 the Foundation for Environmental Conservation will be co-publishing the first of its planned 'Original Paperbacks: Readers by Leaders'. Entitled Environmental Challenges: From Stockholm to Rio and Beyond, it has a Foreword by Mrs Gro Harlem Brundtland and an Introduction by its Editors, Mohammad Nazim \& Nicholas Polunin, with early chapters by Mostafa K. Tolba, Nafis Sadik, Brigitta Dahl, and Arthur H. Westing; included among later chapters are those headed by Bert Bolin, Sandro M. Radicella, and Maurice F. Strong. The price (including postage) will be US $\$ 12$ for individuals and US $\$ 18$ for institutions.

\section{5) World Who's Who in Environment \& Conservation}

After years of preparation, work is now proceeding apace on the Foundation's long-planned World Who's Who in Environment \& Conservation: Leading Specialists, Administrators, and Benefactors, which is planned to contain, besides helpful Appendixes, detailed biographies of the $c .3,000$ seemingly most eminent and/or active living men and women involved in this all-important duality of subjects. Being a large undertaking for a tiny office, it is expected to take another three years to complete and see through the press, with publication most likely in the Winter of 1996-7.

\author{
(Mrs) Lynn M. CURME \\ Environmental Conservation \\ 7 Chemin Taverney \\ 1218 Grand-Saconnex \\ Geneva, Switzerland: \\ Tel. $(++4122) 7982383$ and 4 \\ Fax (++4122) 7982344.
}

\footnotetext{
* Published quarterly for the Foundation by Elsevier Sequoia SA, PO Box 564, 1001 Lausanne 1, Switzerland, and available from them at 275 Swiss francs or $c$. US $\$ 185$ for 1993 (including handling and postage, with air delivery to 19 leading countries).

$\dagger$ New prices in deference to increased postal rates and inflation.
} 